\title{
Structural Fire Design-Statement on the Design of Cross-Laminated Timber (CLT)
}

\author{
Schmid J*, Werther N, Klippel M and Frangi A \\ ETH Zürich, Switzerland \\ ETH Zürich, IGNIS-Fire Design Consulting, Switzerland, TU Munich, Germany
}

Submission: February 26, 2019; Published: March 22, 2019

*Corresponding author: Joachim Schmid, ETH Zürich, Switzerland

Abstract

Recently, some comments about Cross-Laminated Timber (CLT) appeared in journals, online press and lobby documents that highlighted "inconsistencies" of the product when it comes to its fire safe use. The actual document summarizes relevant fire characteristics of CLT, which were brought up, and addresses them accordingly with respect to common understanding, established experience, European standardization and available design guidance. This document shows that currently fire design is not fully covered by codes, but safe design is possible using additional sources as guideline and state of the art documents. The authors of this document share the opinion with CEN/TC 250/SC5/WG4 that fire safe design of CLT is achieved when actual state of the art guidance is followed.

\section{General}

Currently, the most important European fire design code for timber structures, Eurocode 5 (EN 1995-1-2 [1]) is under revision and the next generation is being drafted by the CEN/TC 250/SC5 Project Team working on task SC5.T4 according to the mandate M/515. One of the tasks is to include the fire design of Cross-Laminated Timber (CLT) in the Eurocode 5. The fire performance of CLT as one of the newer timber products was addressed in countless research projects since the year 2000 but is currently not explicitly covered in the Eurocode 5 from the year 2004. Aim of this document is to address the actual comments about fire design using CLT. The overview given in this document can be used as starting point for guidance about current CLT fire design. These state-of-the-art documents will be used in currently executed updating of European design standards.

\section{Building Product Description CLT}

Cross-Laminated Timber (CLT) is a structural timber consisting of at least three bonded layers of which a minimum of three are orthogonally arranged. The product is characterised in a EAD [2] (European Assessment Document, ETAG 019) by EOTA (European Organisation for Technical Assessment) and the product standard EN 16351 [3] by CEN (European Committee for Standardization). Member of these committees are representatives from engineering offices, industry, authorities and research. The reaction to fire properties and the fire resistance design are addressed in the above-mentioned standard documents [2,3] together with the current design standard for timber structures, the Eurocode 5 [1]. Reasons for some shortcomings of the actual Eurocode when it comes to the design of CLT is the issuing date of the Eurocode in the year 2004. In the meantime, European building associations and research consortia have been providing complementary knowledge and design rules with respect to CLT design which should be used until the revised Eurocode will be released in 2022, as currently planned. Several guidance documents were drafted by industry representatives and researchers from among others UK, GER, SE, $\mathrm{CH}, \mathrm{AT}, \mathrm{FR}$, e.g. [4-7].

\section{Fire design basics for CLT}

The fire resistance is either tested and classified by EN 13501 [8] or calculated in accordance with Eurocode 5 [1]. As for other timber products, the structural fire design of CLT is mainly based on the reduction of its cross section due to char resulting in a residual (virgin) cross section. Charring rates have been studied extensively for timber members in general and are given in Eurocode 5 for various phases and fires. Also, for CLT numerous studies have been conducted. In most of the applications, charring rates under standard fire are used to estimate the residual cross section for initially unprotected or protected members or layered assemblies. Standard fire exposure is considered as a measure of comparison and its fire exposure conditions corresponds to a post flash over fire (a fully developed fire is typically ventilation controlled, i.e. the compartment oxygen concentration is close to 


\section{Civil Engineering Research Journal}

zero as all inflowing oxygen is consumed) [9]. If required, e.g. due to authority requests, additional fire load by the compartment structure (combustible parts of walls and floors) could be considered using parametric fire exposure (Annex A of Eurocode 5). These models can be applied also for CLT structures [12,30].

\section{Recently raised questions}

Recently raised questions on the fire performance of CLT concern (a) the charring rate of CLT, (b) the fire protection of CLT by linings, (c) the possibilities for extinguishing by fire fighters, (d) the fuel by the member, (e) the influence to external fire spread and (f) about the detailing in CLT structures.

A. The charring behaviour of CLT: Charring rates of CLT are in agreement with the actual model in Eurocode 5. As for any timber member exposed to standard fire, the charring rates for CLT vary between zero millimetre per minute (encapsulated) and about 1.3 millimetre per minute (after failure of a protective layer or fall-off of charring layers until a protective char layer has been formed again). There are numerous of studies available, e.g. [10-14]. In general, CLT is considered as either a solid timber product or as a layered timber assembly if a fall-off of charring layers can be expected during a fire. This is when the adhesive is not able providing glue line integrity during the fire exposure. In this case (fire induced debonding), the so-called stepped model [15] combines a basic charring rate with a doubled value to consider exposure of fresh, virgin wood if fall-off of charring layers would occur. Figure 1 shows the agreement of the model and furnace tests $\left(45^{\circ}\right.$-line corresponds to a perfect fit). Recent compartment experiment results fit the model although the fire exposure is different [16]. Investigations by the same authors show charring of 0.4 to 0.7 millimetre per minute for nonstandard heating [17].

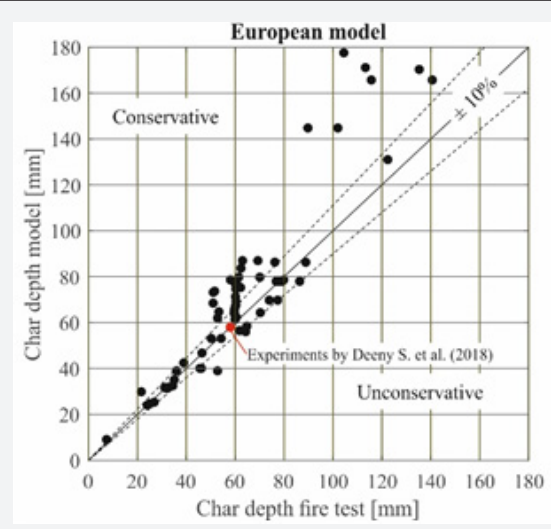

Figure 1: Comparison of the charring depth measured in tests (horizontal axis) and the Eurocode (vertical axis), modified from [15].

\section{B. The fire protection of CLT by linings}

Fire protection by linings made from gypsum plaster and -fibre boards use the advantage of the high amount of bound water and are typically applied to steel or timber structures $[18,19]$. The protection ability is a characteristic defined by the assembly including the fire protection system, the fixation (e.g. screws) and the material backing the lining (substrate). The encapsulation function of linings is currently assessed on low and medium density wood-based boards according to EN 14135 [20] resulting in K-classes preventing charring behind the covering. Further, the contribution of the protection to the fire resistance can be assessed by means of EN 13381-7 [21] describing the eventual charring behind the protection system and its failure. Crucial for any lining used as fire protection is the fall-off allowing for a significant temperature rise of the element behind. Around the globe, linings as fire protection are well researched, e.g. [2223]. The future Eurocode 5 will improve generic protection data already available in the current version which will be based on minimum provided protection. In compartment fires, fall-off of linings occurs generally later compared to standard fire testing $[24,25]$. In comparison to steel or timber frame structures, the fall-off of linings applied to CLT is later due to the lower heat accumulation in the protective lining and the possibility for improved fixation by screws (increased offset from the edges). If the spacing and anchorage of screws is done properly, double layer fire rated boards Type $\mathrm{F}$ [18] prevent direct fire exposure for more than $60 \mathrm{~min}$. Fall-off at $22.6 \mathrm{~min}$ as specified in [16] indicates severe fixation problems or other wrong application of the lining used.

\section{The extinguishing of CLT structures}

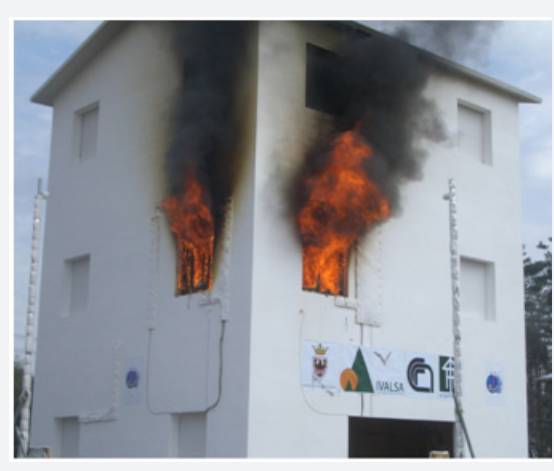

Figure 2: So called natural full-scale fire tests performed in Japan 2006 [27].

Fire accidents do not follow a plan and are difficult to predict. Reasonable measures should be taken to limit the consequences. Due to the nature of fires their development may vary significantly independent on the structural material. Thus, fire resistance tests following standard fire exposure are a commonly accepted measure of comparison as they provide a defined fire exposure for the tested product - independent of the material - similar to a post flash over fire $[9,26]$. The repeatability of compartment tests is low as the test boundary conditions cannot be controlled entirely. However, numerous compartment tests have been performed also with CLT with various purposes. Introducing CLT on the market, experiments have been performed in coordination with fire services to assess the capability to extinguish these compartments with common 


\section{Civil Engineering Research Journal}

methods (Figure 2). It was found that these fires are typically not more difficult to extinguish as other fires, e.g. [27-28]. The solid nature of CLT contributes to this behaviour by excluding internal flame spread. To experts, it is known that wood as compartment boundaries leads to a faster temperature rise and insignificantly higher maximum temperatures due to the lower thermal inertia of wood compared to e.g. concrete [9,29]. This behaviour is not connected to the combustibility of the product.

\section{The fuel by the structure}

Depending on the design requirements, the available fuel (fire load) can be considered and, thus, design fires for the particular project can be determined. The movable fire load (combustible interior) in an compartment is a statistically distributed number; normally values with a reasonable safety margin are used. In contrary, eventually available fire load provided by wood linings or wood structures can be assessed accurately. Proposed procedures base on the iteration of fire duration and char depth $[12,30]$. Guidance to consider the influence of exposed timber to the fire scenario are also included in the Finnish building regulations, based on extensive investigations [31]. A significant share of the structure's pyrolysis products will not combust in a post flashover fire (phase with very limited oxygen availability) but outside the compartment at the façade, see (E).

After the introduction of CLT, in numerous studies the glue line integrity (fire induced debonding) was studied intensely in furnace and compartment tests, e.g. $[15,28]$. It was found that some products tend to show debonding. Debonding results in accelerated charring as the product loses its protection by the char layer which is added to the fuel, exposed virgin wood undergoes accelerated charring and guidance was given to engineers addressing this behaviour using the stepped model for charring, see (A). However, extinguishing experiments, see (C), showed that no problem was found to extinguish compartments where debonding had occurred. In 2018, a method was introduced to test CLT with respect to the assessment of fire induced debonding for CLT [32], which may result in extended compartment fires. A European test method is currently under development by the industry based on available research [33].

\section{E. The external fire spread}

Fuel, regardless its origin, which is not ignited within a fire compartment during a post flashover fire (where only very limited amount of oxygen is available) will be pushed as gas through the compartment openings where it will ignite at the façade. Depending on the fire load in the compartment and availability of oxygen (characterised by the openings), the share of the fuel combusting at the façade can be $30 \%$ to $70 \%$. The effects on the external flaming at the façade of combustible compartment surfaces have been studied before the introduction of CLT [34]. The peak heat release rates in front of the facades of compartments with various parameters (size of compartment and window openings, shares of linings) were investigated and typically values between 8 and 15MW were found [34].
The peak contribution by CLT was determined to be between 2 and 6MW [25,35]), see also Figure 3. For fire design experts the consequence of the increase is the application of noncombustible facades which should be a standard procedure for any high rise building regardless the main structural material. In an analytical performance-based design some countries allow for modification of this standard procedure.

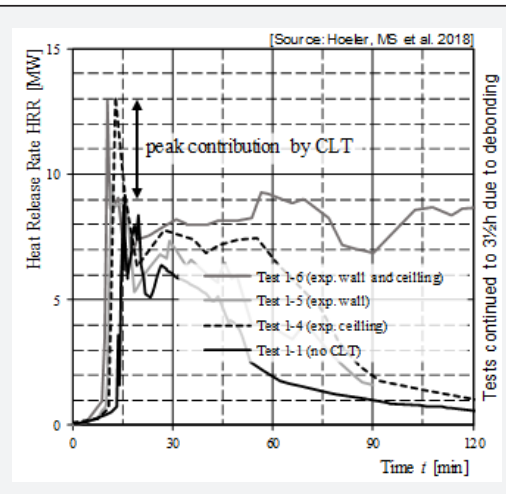

Figure 3: Comparison of compartment heat release with and without exposed CLT [35].

\section{F. Detailing in CLT structure}

The general fire safety objectives have to be fulfilled by the entire structure and for each type of construction. Beside the structural elements - in-plane joints to neighbouring elements, joints in junctions to other building parts and joints resulting from service installations shall be designed accordingly. The prejudice of an insufficient fire safety detailing within CLT structures due to the lack of experience can be refuted by the performed extensive test series on CLT elements and in CLT compartments with standard and natural fire exposure within the last years [36]. Especially measures like the exclusion of continuous joints, the reduction of joint tolerances, the filling of larger gaps, the application of structural connections like step joints, tongue and groove and external splines in combination with the exclusion of convective paths by applying air tightness can be mentioned as relevant measures to ensure an overall fire safety. Also, the fire safety for service installations was investigated extensively in combination with CLT and general concepts, like the lining of the reveal area and approved producer specific systems were developed and introducedin the market [4,37]. Design guidance is available in several national publications and the international online catalogues like dataholz.eu $[10,38,39]$.

\section{Conclusion}

The presented summary shows that substantial knowledge about the fire safe design with CLT is available in standards, guidelines, design documentation and online catalogues. The product standard and technical assessment documents provide the legal basis in the application of CLT. Whilst the structural fire design of CLT elements under standard fire exposure can be covered by the knowledge and design rules in Eurocode 5, recommendations for detailing are currently included in national 


\section{Civil Engineering Research Journal}

specific guidelines. Also, the knowledge about the interaction and contribution of CLT to the fire scenario is existing and was used within the design of innovative multi storey timber buildings around the world in the last years Kaufman et al. [38]. Even if the fire safe design product specific knowledge of CLT is existing, further optimisation and standardisation is needed for an improved fire design which is content of actual and planned research projects. It seems essential that these research consortia are of international origin to address the building design traditions in various countries and spread the knowledge globally.

\section{References}

1. EN 1995-1-2 (2004) Eurocode 5: Design of timber structures.

2. EAD 130005-00-034 (2015) European Assessment Document EAD. Solid Wood Slab Element to be used as Structural Element in Buildings, EOTA, 2015-03.

3. EN 16351 (2015) Timber structures-Cross laminated timber: Requirements.

4. Östman B, Bregulla J, Mikkola E, Stein R, Frangi A, et al. (2010) Fire safety in timber buildings. Technical guideline for Europe. ISBN 97891-86319-60-1, EU science HUB, p. 1-88.

5. Falk A, Dietsch P, Schmid J (2016) Cross Laminated Timber-A competitive wood product for visionary and fire safe buildings. Proceedings of the Joint Conference of COST Actions FP1402 \& FP1404 Stockholm.

6. Klippel M, Just A (2018) Guidance on Fire design of CLT including best practise. COST Action FP1404, Zürich, Switzerland.

7. Gräfe, M, Merk, M, Werther, N, Fülle C, Leopold N, et al. (2015) Detail catalogue for multistory timber buildings (in German) Regeldetailkatalog für den mehrgeschossigen Holzbau in Gebäudeklasse 4, Fraunhofer IRB Verlag, Stuttgart, Germany.

8. EN 13501-2 (2016) Fire classification of construction products and building elements.

9. Schmid, J, Brandon D, Werther N, Klippel M (2018) Thermal exposure of wood in standard fire resistance tests, Fire Safety Journal.

10. Teibinger, M, Matzinger, I (2013) Construction with Cross-Laminated Timber in Multi-Storey Buildings-Focus on Building Physics. Wien, Österreich: Holzforschung Austria 35(5): 45-345.

11. Frangi A, Fontana M, Hugi E, Jöbstl R (2009) Experimental analysis of cross-laminated timber panels in fire. Fire Safety Journal 44(8):10781087.

12. Friquin KL, Grimsbu M, Hovde PJ (2010) Charring rates for crosslaminated timber panels exposed to standard and parametric fires. Proceedings of the World conference on timber Engineering (WCTE 2010), University of Bath, England, UK.

13. Klippel M, Leyder CL, Frangi A, Fontana MA (2014) Fire tests on loaded cross-laminated timber wall and floor elements. Fire Safety Science 11: 626-639.

14. Hasburgh L, Bourne K, Dagenais C, Ranger L, Roy-Poirier A (2016) Fire performance of mass-timber encapsulation methods and the effect of encapsulation on char rate of cross-laminated timber. Proceedings of the World conference on timber Engineering (WCTE 2016), NRCC Canada.

15. Klippel M, Schmid J (2017) Design of Cross-Laminated Timber in Fire Structural Engineering International.
16. Deeny S, Lane B, Hadden, R, Lawrence, A (2018) Fire safety design in modern timber buildings, Structural fire engineer.

17. Bartlett A, Hadden R, Bisby L, Law A (2015) Analysis of crosslaminated timber charring rates upon exposure to non-standard heating conditions. Proc. of the Conference Fire and Materials 2015, San Francisco, CA, USA

18. EN 520 (2004) Gypsum plasterboards. Definitions requirements and test methods

19. EN 15283-2 (2008) Gypsum boards with fibrous reinforcement Definitions, requirements and test methods.

20. EN 14135 (2005) Coverings -Determination of fire protection ability.

21. EN 13381-7 (2019) Test methods for determining the contribution to the fire resistance of structural members-Part 7: Applied protection to timber members.

22. Sultan MA (2008) Gypsum board performance in fire rated floor assemblies. NRCC-50275, National Research Council Canada.

23. Just A, Schmid J, König J (2010) Failure times of gypsum boards. Proceedings of the 6th international conference Structures in Fire: Structures in Fire, East Lansing, USA, 2.-4.6. Des Tech Publications Inc, USA, pp. 593-601.

24. Su J, Lafrance PS, Hoehler M, Bundy M (2018) Fire Protection Research Foundation report: "Fire Safety Challenges of Tall Wood Buildings - Phase 2: Tasks 2 \& 3-Development and Implementation of CLT Compartment Fire Tests.

25. McGregor CJ (2013) Contribution of Cross Laminated Timber Panels to Room Fires. Carleton University, Canada, pp. 1-186.

26. EN 1363-1 (2012) Fire resistance tests. General requirements.

27. Frangi A, Bochicchio G, Ceccotti A, Lauriola MP (2008) Natural FullScale Fire Test on a 3 Storey XLam Timber Building, Proceedings of the World conference on timber Engineering (WCTE 2008), Florence, Italy.

28. Just, A, Brandon D, Mäger KM, Pukk R, Sjostrom J, Kahi F (2018) CLT Compartment Fire Test, Proceedings of the World conference on timber Engineering (WCTE 2018), Florence, Italy.

29. Hadden RM, Bartlett AI, Hidalgo JP, Santamaria S, Wiesner F, et al. (2017) Effects of exposed cross laminated timber on compartment fire dynamics. Fire Safety Journal 91: 480-489.

30. Brandon D, Kagiya K, Hakkarainen T (2018) Performance based design for mass timber structures in fire Design-Calculation Example. COST Action FP1404, Zürich, Switzerland.

31. Mikkola, E, Rinne T, Granström M (2017) Extended use of massive wood structures without coverings-arguments for revision of the fire safety regulations, KK-PALOKONSULTTI OY

32. ANSI/APA PRG 320 (2018) Standard for Performance-Rated CrossLaminated Timber.

33. Klippel M, Schmid J, Fahrni R, Frangi A (2018) Assessing the adhesive performance in CLT exposed to fire. Proceedings of the World conference on timber Engineering (WCTE 2018), Seoul, Republic of Korea.

34. Hakkarainen T (2002) Post-flashover fires in light and heavy timber construction compartments. Journal of Fire Science 20(2): 2002.

35. Hoehler MS, Su J, Lafrance PS, Bundy MF, Kimball A, et al. (2018) Fire Safety Challenges of Tall Wood Buildings: Large Scale Cross Laminated Timber Compartment Fire Test, International Conference on Structures in Fire (SIF 2018), Belfast, UK.

36. Dataholz.eu (2019) online design catalogue, Holzforschung Austria. 


\section{Civil Engineering Research Journal}

37. Egenhofer M (2017) Brandabschottungen im Holzbau, Master Thesischair for timber structures and building construction, TU Munich, Germany.

38. Kaufmann H, Krötsch S, Winter S, (2018) Atlas Mehrgeschossiger Holzbau, Detail Verlag.
39. Rauch M et al (2018) Evaluation of the Component Additive Method until 90 minutes fire exposure-presentation slides. finale conference COST Action FP1404, Zürich, $1^{\text {st }}$ and $2^{\text {nd }}$ October 2018, Switzerland.

40. Werther N, Denzler JK, Stein R, Winter S (2016) Detailing of CLT with respect to fire resistance. Proceedings of the Joint Conference of COST Actions FP1402 \& FP1404 KTH Building Materials.

\section{Your next submission with Juniper Publishers} will reach you the below assets

- Quality Editorial service

- Swift Peer Review

- Reprints availability

- E-prints Service

- Manuscript Podcast for convenient understanding

- Global attainment for your research

- Manuscript accessibility in different formats

( Pdf, E-pub, Full Text, Audio)

- Unceasing customer service

Track the below URL for one-step submission https://juniperpublishers.com/online-submission.php 